\title{
Penerapan Media Audio-Visual dalam Meningkatkan Hasil Latihan Teknik Dasar Dollyo Chagi pada Peserta Ekstrakurikuler Taekwondo di SMA
}

\author{
Muhamad Arfliza Ilham Riski, Sugiyanto* \\ Universitas Negeri Malang, Jl. Semarang No. 5 Malang, Jawa Timur, Indonesia \\ *Penulis korespondensi, Surel: sugiyanto0um@gmail.com
}

Paper received: 1-10-2021; revised: 19-10-2021; accepted: 25-10-2021

\begin{abstract}
The purpose of this study is to examine and description the application of audio-visual media and enhance the basic training result of dollyo chagi in application audio-visual media for extracurricular participant taekwondo in SMA. This research is sport action study (PTO). This research use descriptive qualitative and quantitative method. The sample of this study has 11 participant with 6 male participant and 5 female participant category. The instrument used is observing guidelines for activities extracurricular participants for qualitative data and assessment basic training dollyo chagi for quantitative data. The results of show percentage whole participants before action is 3 percent. After that cycle I be an 81 percent and cycle II to 91 percent. Unfortunately, participant's activity before action reach 81 percent and include to category "Cukup". Thus, it can be concluded that audiovisual media can enhance basic training result of dollyo chagi for extracurricular participant taekwondo in SMA. Audio-visual media can be helper for extracurricular activity for coach to be enhanced training result.
\end{abstract}

Keywords: dollyo chagi; audio-visual media; articulate storyline

\begin{abstract}
Abstrak
Tujuan penelitian ini untuk mengkaji dan mendeskripsikan penerapan media audio-visual dan peningkatan hasil latihan teknik dasar dollyo chagi dalam penerapan media audio-visual pada peserta ekstrakurikuler taekwondo di SMA. Penelitian ini merupakan penelitian tindakan olahraga (PTO). Penelitian ini menggunakan metode deskriptif kualitatif kuantitatif. Sampel penelitian ini berjumlah 11 peserta dengan kategori 6 peserta laki-laki dan 5 peserta perempuan. Instrumen tes yang digunakan adalah kisi-kisi pedoman observasi aktivitas latihan peserta ekstrakurikuler untuk data kualitatif dan rubrik penilaian teknik dasar dollyo chagi untuk data kuantitatif. Hasil data penelitian menunjukkan persentase hasil latihan peserta secara keseluruhan sebelum tindakan berada pada 3 persen. Setelah dilakukan tindakan pada siklus I menjadi 82 persen dan pada siklus II sebesar 91 persen. Sedangkan untuk aktivitas peserta sebelum tindakan mencapai angka 81 persen yang dikategorikan cukup. Dengan demikian dapat disimpulkan bahwa media audio-visual dapat meningkatkan hasil latihan teknik dasar dollyo chagi peserta ekstrakurikuler taekwondo di SMA. Media audio-visual disarankan dapat dijadikan media bantu kegiatan ekstrakurikuler oleh pelatih untuk mengoptimalkan hasil latihan.
\end{abstract}

Kata kunci: dollyo chagi; media audio-visual; articulate storyline

\section{Pendahuluan}

Pendidikan adalah usaha terencana yang dilaksanakan pendidik dalam menyelenggarakan kegiatan pengembangan diri peserta didik menjadi manusia yang memiliki ilmu dan bijak sesuai dengan tujuan pendidikan itu sendiri. Salah satu wadah dalam mengemban pendidikan adalah sekolah. Sekolah sebagai organisasi memiliki banyak aktivitas untuk mencapai suatu tujuan (Wiyani, 2013) salah satunya adalah kegiatan ekstrakurikuler. 
Kegiatan ekstrakurikuler merupakan kegiatan yang dilakukan di luar jam kegiatan pembelejaran untuk mengambangkan bakat dan minat serta potensi diri peserta didik baik yang bersifat akademik maupun non-akademik (Kompri, 2015). Kegiatan ekstrakurikuler memiliki beragam kegiatan di setiap sekolah.

Taekwondo merupakan seni beladiri modern yang berasal dari negara korea selatan. Taekwondo sendiri memiliki arti dan terdiri dari 3 kata yaitu, tae yang artinya melancarkan serangan dengan menggunakan kaki sebagai senjata utama atau biasa disebut dengan teknik tendangan, kwon yang memiliki arti menyerang dan melindungi diri dengan menggunakan tangan untuk menangkis serangan yang dilancarkan lawan serta sebagai teknik memukul sebagai senjata kedua selain kaki, do yang artinya suatu seni bela diri yang bermaksud untuk menjadikan diri menjadi sosok yang lebih disiplin dalam melakukan berbagai gerakan (Suryadi, 2003). Lebih lanjut, Suryadi (2003) taekwondo memiliki beberapa tendangan dasar untuk dikuasai, seperti tendangan dollyo chagi, deol o chagi, ap chagi, dan yeop chagi. Beberapa tendangan yang telah disebutkan memiliki ciri khas dan teknik tersendiri dalam memahami, mempelajari dan pelaksanaannya. Dari keempat tendangan tersebut, dollyo chagi merupakan tendangan yang sering dilakukan dalam setiap pertandingan. Hasil penelitian (Rachmahani, 2017) mengatakan bahwa tendangan yang efektif digunakan dalam pertandingan taekwondo di kejuaraan upi ialah dollyo chagi dengan kategori putra sebanyak 20,11\% dan kategori putri sebanyak $13,74 \%$. Selain itu, dollyo chagi merupakan tendangan yang efektif karena tidak hanya kuat dalam melakukan serangan melainkan juga berguna untuk memperhatikan reaksi kaki lawan saat melakukan tipuan (Bremacker \& Faige, 2010).

Latihan dollyo chagi bagi peserta didik dapat dilakukan dengan mengikuti kegiatan ekstrakurikuler di sekolahnya masing-masing atau dapat masuk ke dalam klub yang ada di wilayahnya, salah satunya yaitu kegiatan ekstrakurikuler taekwondo di SMA. Temuan lapangan yang dilakukan pada kegiatan ekstrakurikuler taekwondo di SMA bisa dikatakan berada dalam kondisi yang kurang baik, dikarenakan waktu yang tidak mendukung dan sarana yang kurang luas dalam pelaksanaannya sehingga membuat peserta harus bergantian untuk mempraktekkan tendangan yang diajarkan dan memakan waktu yang lama. Oleh karena itu, terdapat beberapa peserta didik yang asal-asalan dalam melakukan tendangan dan juga pengawasan yang dilakukan pelatih menjadi berkurang untuk memperbaiki gerakan yang kurang benar. Latihan sendiri merupakan kegiatan yang harus dilakukan secara sistematis dan terprogram (Amiq, 2015) agar setiap gerakan yang dilakukan tidak terbuang sia-sia.

Berdasarkan hasil wawancara dengan pelatih ekstrakurikuler taekwondo di SMA, bahwa kegiatan ekstrakurikuler memiliki beberapa kendala dalam proses pengaplikasian teknik dasar tendangan yang baik dikarenakan kurangnya waktu pelaksanaan yang dilakukan yang membuat kurangnya pengawasan dan perbaikan terhadap teknik yang kurang baik. Hal ini dibuktikan dengan adanya pengambilan data awal berupa tes praktek teknik tendangan dasar yang berjumlah 4 pada kegiatan ekstrakurikuler taekwondo yaitu, dollyo chagi, deol o chagi, ap chagi dan yeop chagi. Hasil yang diperoleh berbentuk persentase skor (\%) yaitu; (1) nilai dollyo chagi 53,7\%, (2) nilai deol o chagi 57,4\%, (3) nilai ap chagi 59,7\% dan (4) nilai yeop chagi 57,8\%. Persentase skor yang diperoleh dari 11 peserta membuktikan bahwa kemampuan teknik dollyo chagi mendapatkan skor terendah dari 3 tendangan lainnya. Hasil ini menyebabkan perlu adanya alternatif pendukung agar hasil teknik dollyo chagi dapat lebih baik dari segi teknik dasarnya, salah satu solusinya menggunakan bantuan media dalam 
mempermudah peserta memahami dan mengaplikasikan teknik dasar yang diajarkan untuk mencapai hasil yang lebih baik.

Pemanfaatan media salah satunya sebagai alternatif pengaplikasian dalam mengajar untuk mempermudah peserta dalam memahami materi sehingga mencapai tujuan yang diinginkan (Surjono, 2017) yaitu salah satunya teknik dasar dollyo chagi pada kegiatan ekstrakurikuler taekwondo. Media merupakan wadah informasi yang disalurkan kepada penerima untuk mencapai tujuan berupa pesan dan proses pembelajaran atau latihan (Muhson, 2010). Media yang dipilih pada kegiatan ekstrakurikuler ialah media audio-visual sebagai wadah untuk mempelajari teknik dasar dollyo chagi. Media ini menggunakan bantuan aplikasi articulate storyline untuk menayangkan berbagai video yang digunakan untuk mengaplikasikan teknik dasar dollyo chagi.

Penelitian ini diperkuat dengan penelitian sebelumnya oleh Louk, Neolaka \& Runesi (2020) bahwa media audio-visual dapat memberikan hasil yang positif dan juga dapat meningkatkan hasil belajar siswa, karena melalui audio-visual ini siswa dapat melihat fase demi fase gerakan yang ada dalam permainan futsal. Selanjutnya, penelitian ini juga diperkuat oleh penelitian sebelumnya oleh Setianto (2017) bahwa produk pengembangan latihan taekwondo dengan media audio-visual untuk ekstrakurikuler taekwondo menarik, menyenangkan, aman, mudah dan bermanfaat untuk latihan taekwondo sehingga layak untuk digunakan pada latihan taekwondo di SMA.

Berdasarkan latar belakang masalah yang telah dipaparkan sebelumnya, maka peneliti tertarik untuk menggunakan media audio-visual sebagai media dalam membantu peserta mengaplikasikan teknik dollyo chagi dalam kegiatan ekstrakurikuler taekwondo dengan judul penelitian "Penerapan Media Audio-Visual dalam Meningkatkan Hasil Latihan Teknik Dasar Dollyo Chagi pada Peserta Ekstrakurikuler Taekwondo di SMA".

\section{Metode}

Penelitian ini merupakan penelitian tindakan olahraga (PTO). Penelitian ini menggunakan metode deskriptif kuantitatif kualitatif. Penelitian ini dilakukan di SMA 3 Batu. Subjek pada penelitian ini terdiri atas 11 peserta ekstrakurikuler yang dikategorikan 6 peserta laki-laki dan 5 peserta perempuan. Teknik pengumpulan data yang digunakan melalui wawancara, tes, dan dokumentasi. Alat pengumpulan data adalah kis-kisi pedoman wawancara.

Instrumen tes yang digunakan dalam penelitian tindakan olahraga berupa tes praktik sebagai data kuantitatif berupa rubrik penilaian teknik dasar dollyo chagi. Dan data kualitatif diambil melalui kisi-kisi pedoman observasi aktivitas latihan peserta ekstrakurikuler yang nantinya akan dideskripsikan sesuai dengan kategori dalam kriteria keberhasilan aktivitas latihan. 
Tabel 1. Kriteria Keberhasilan Aktivitas Latihan

\begin{tabular}{cc}
\hline Interval Nilai & Kategori \\
\hline $81-100 \%$ & Sangat Baik \\
$61-80 \%$ & Baik \\
$41-60 \%$ & Cukup Baik \\
$21-40 \%$ & Kurang Baik \\
$0-20 \%$ & Tidak Baik \\
\hline
\end{tabular}

\section{Hasil dan Pembahasan}

Data pada penelitian ini dibagi menjadi 2 yaitu siklus I dan siklus II. Data yang didapatkan telah dipaparkan yaitu.

\subsection{Siklus I}

Data yang diperoleh berasal dari pengamatan pada siklus I selama proses kegiatan ekstrakurikuler taekwondo berlangsung. Hasil pengamatan aktivitas latihan teknik dasar dollyo chagi disajikan dalam tabel 2 sebagai berikut.

Tabel 2. Aktivitas Latihan Teknik Dasar Dollyo Chagi Siklus I

\begin{tabular}{|c|c|c|c|}
\hline No. & Aktivitas Latihan & $\begin{array}{l}\text { Jumlah } \\
\text { Peserta }\end{array}$ & Keterangan \\
\hline \multicolumn{4}{|c|}{ Aktivitas Visual } \\
\hline 1. & $\begin{array}{l}\text { Peserta memperhatikan video } \\
\text { demonstrasi teknik dasar dollyo } \\
\text { chagi }\end{array}$ & 9 & $\begin{array}{l}\text { Terdapat } 2 \text { peserta yang sering melamun } \\
\text { atau pandangan teralihkan ke jalan raya }\end{array}$ \\
\hline 2. & $\begin{array}{l}\text { Peserta memperagakan teknik } \\
\text { dasar dollyo chagi sesuai dengan } \\
\text { yang diperagakan pelatih dan } \\
\text { media. }\end{array}$ & 11 & $\begin{array}{l}\text { Peserta ekstrakurikuler memperagakan } \\
\text { teknik dasar dollyo chagi }\end{array}$ \\
\hline \multicolumn{4}{|c|}{ Aktivitas Mendengarkan } \\
\hline 3. & $\begin{array}{l}\text { Peserta ekstrakurikuler } \\
\text { mendengarkan suara dalam } \\
\text { media untuk mengikuti gerakan }\end{array}$ & 10 & $\begin{array}{l}\text { Terdapat } 1 \text { peserta yang lebih memilih } \\
\text { melihat gerakan peserta lain daripada } \\
\text { mendengarkan suara dalam video }\end{array}$ \\
\hline 4. & $\begin{array}{l}\text { Peserta ekstrakurikuler } \\
\text { menyimak apa instruksi dari } \\
\text { pelatih untuk gerakan yang akan } \\
\text { dilakukan selanjutnya }\end{array}$ & 9 & $\begin{array}{l}\text { Satu peserta yang lebih memilih melihat } \\
\text { gerakan peserta memberikan pengaruh } \\
\text { terhadap peserta lainnya sehingga hanya } \\
\text { mengandalkan gerakan peserta lain. }\end{array}$ \\
\hline \multicolumn{4}{|c|}{ Aktivitas Mental } \\
\hline 5. & $\begin{array}{l}\text { Peserta fokus pada gerakan } \\
\text { teknik dasar yang dilakukan } \\
\text { secara mandiri }\end{array}$ & 7 & $\begin{array}{l}\text { Masih terdapat beberapa peserta yang } \\
\text { lebih memilih melihat gerakan peserta } \\
\text { lainnya. }\end{array}$ \\
\hline 6. & $\begin{array}{l}\text { Peserta ekstrakurikuler } \\
\text { mempraktikkan teknik dasar } \\
\text { dollyo chagi sesuai dengan yang } \\
\text { ditayangkan dalam media }\end{array}$ & 11 & $\begin{array}{l}\text { Peserta ekstrakurikuler mempraktikkan } \\
\text { gerakan teknik dasar dollyo chagi }\end{array}$ \\
\hline \multicolumn{4}{|c|}{ Aktivitas Emosional } \\
\hline 7. & $\begin{array}{l}\text { Peserta ekstrakurikuler senang } \\
\text { mengikuti arahan pelatih dan } \\
\text { video teknik dasar dollyo chagi } \\
\text { yang ada dalam media }\end{array}$ & 7 & $\begin{array}{l}\text { Terlihat peserta antusias dan senang } \\
\text { dengan adanya media namun terdapat } \\
\text { beberapa peserta yang masih asyik } \\
\text { mengobrol sendiri dan bersenda gurau. }\end{array}$ \\
\hline
\end{tabular}




\begin{tabular}{clcl}
\hline No. & Aktivitas Latihan & $\begin{array}{l}\text { Jumlah } \\
\text { Peserta }\end{array}$ & Keterangan \\
\hline 8. & $\begin{array}{l}\text { Peserta ekstrakurikuler } \\
\text { bersemangat dalam mengikuti } \\
\text { kegiatan ekstarkurikuler } \\
\text { taekwondo }\end{array}$ & 8 & $\begin{array}{l}\text { Terdapat 3 peserta yang terlihat lelah di } \\
\text { akhir kegiatan dan kehilangan semangat }\end{array}$ \\
\hline
\end{tabular}

Dari paparan hasil pengamatan aktivitas latihan teknik dasar dollyo chagi pada siklus I oleh peserta ekstrakurikuler taekwondo dapat diketahui terdapat 9 peserta memperhatikan video demonstrasi dan 11 peserta memperagakan teknik dasar sesuai dengan yang diperagakan dalam media, dari hasil tersebut dapat disimpulkan sebesar $91 \%$ dari jumlah keseluruhan peserta melakukan aktivitas visual. Peserta ekstrakurikuler mendengarkan suara sebanyak 10 orang dan 9 peserta menyimak instruksi yang disajikan pelatih, dapat dikatakan 83\% dari jumlah keseluruhan peserta melakukan aktivitas mendengarkan. Terdapat 7 peserta fokus pada gerakan teknik dasar secara mandiri dan 11 peserta mempraktikkan gerakan mengikuti arahan pelatih dan media yang ditampilkan, dapat dikatakan terdapat $81 \%$ dari jumlah keseluruhan peserta melakukan aktivitas mental. Selain itu, 7 peserta juga senang mengikuti arahan pelatih dan 8 peserta bersemangat dalam mengikuti kegiatan menggunakan media, sehingga bisa dilihat $68 \%$ dari jumlah keseluruhan peserta melakukan aktivitas emosional.

Berdasarkan paparan data yang telah didapatkan pada siklus I maka persentase aktivitas latihan teknik dasar dollyo chagi secara keseluruhan adalah $80 \%$ yang dikategorikan masuk dalam kriteria "Baik". Hal ini mengalami kenaikan dari aktivitas latihan sebelum tindakan. Kemudian hasil pengamatan berupa data kuantitatif diperoleh dari pelaksanaan kegiatan evaluasi yang kemudian skor peserta dikonversikan menjadi persentase. Dari hasil yang dikonversikan kemudian diperlihatkan tingkat ketuntasan latihan teknik dasar dollyo chagi pada tabel 3 sebagai berikut.

Tabel 3. Tingkat Ketuntasan Latihan Teknik Dasar Dollyo Chagi Siklus I

\begin{tabular}{|c|c|c|c|c|c|}
\hline \multirow{2}{*}{$\begin{array}{c}\text { Tingkat } \\
\text { Keberhasilan }\end{array}$} & \multicolumn{3}{|c|}{ Jumlah Peserta } & \multirow{2}{*}{$\begin{array}{c}\text { Keseluruhan } \\
\text { Peserta }\end{array}$} & \multirow[t]{2}{*}{ Persentase } \\
\hline & Pelatih I & Pelatih II & Peneliti & & \\
\hline Tercapai & 9 & 9 & 9 & 11 & $82 \%$ \\
\hline Belum Tercapai & 2 & 2 & 2 & 11 & $8 \%$ \\
\hline
\end{tabular}

Berdasarkan data hasil belajar pada siklus I menunjukkan bahwa jumlah keseluruhan peserta ekstrakurikuler 11, terdapat 2 peserta didik dari masing-masing pelatih yang belum tercapai atau mendapatkan perolehan skor $\leq 70,9$ peserta lainnya memperoleh skor $\geq 70$. Persentase ketuntasan secara keseluruhan adalah 9 peserta ekstrakurikuler sebesar $82 \%$ dan bisa disimpulkan adanya peningkatan dari sebelum tindakan menuju siklus I.

\subsection{Siklus II}

Data yang diperoleh berasal dari pengamatan pada siklus II selama proses kegiatan ekstrakurikuler taekwondo berlangsung. Hasil pengamatan aktivitas latihan teknik dasar dollyo chagi disajikan dalam tabel 4. 
Tabel 4. Aktivitas Latihan Teknik Dasar Dollyo Chagi Siklus II

\begin{tabular}{|c|c|c|c|}
\hline No. & Aktivitas Latihan & $\begin{array}{l}\text { Jumlah } \\
\text { Peserta }\end{array}$ & Keterangan \\
\hline \multicolumn{4}{|c|}{ Aktivitas Visual } \\
\hline 1. & $\begin{array}{l}\text { Peserta memperhatikan video } \\
\text { demonstrasi teknik dasar dollyo } \\
\text { chagi }\end{array}$ & 10 & $\begin{array}{l}\text { Terdapat } 2 \text { peserta yang } \\
\text { sering melamun atau } \\
\text { pandangan teralihkan ke jalan } \\
\text { raya }\end{array}$ \\
\hline 2. & $\begin{array}{l}\text { Peserta memperagakan teknik } \\
\text { dasar dollyo chagi sesuai } \\
\text { dengan yang diperagakan } \\
\text { pelatih dan media. }\end{array}$ & 11 & $\begin{array}{l}\text { Peserta ekstrakurikuler } \\
\text { memperagakan teknik dasar } \\
\text { dollyo chagi }\end{array}$ \\
\hline \multicolumn{4}{|c|}{ Aktivitas Mendengarkan } \\
\hline 3. & $\begin{array}{l}\text { Peserta ekstrakurikuler } \\
\text { mendengarkan suara dalam } \\
\text { media untuk mengikuti gerakan }\end{array}$ & 9 & $\begin{array}{l}\text { Terdapat } 1 \text { peserta yang lebih } \\
\text { memilih melihat gerakan } \\
\text { peserta lain daripada } \\
\text { mendengarkan suara dalam } \\
\text { video }\end{array}$ \\
\hline 4. & $\begin{array}{l}\text { Peserta ekstrakurikuler } \\
\text { menyimak apa instruksi dari } \\
\text { pelatih untuk gerakan yang } \\
\text { akan dilakukan selanjutnya }\end{array}$ & 11 & $\begin{array}{l}\text { Satu peserta yang lebih } \\
\text { memilih melihat gerakan } \\
\text { peserta memberikan } \\
\text { pengaruh terhadap peserta } \\
\text { lainnya sehingga hanya } \\
\text { mengandalkan gerakan } \\
\text { peserta lain. }\end{array}$ \\
\hline \multicolumn{4}{|c|}{ Aktivitas Mental } \\
\hline 5. & $\begin{array}{l}\text { Peserta fokus pada gerakan } \\
\text { teknik dasar yang dilakukan } \\
\text { secara mandiri }\end{array}$ & 10 & $\begin{array}{l}\text { Masih terdapat beberapa } \\
\text { peserta yang lebih memilih } \\
\text { melihat gerakan peserta } \\
\text { lainnya. }\end{array}$ \\
\hline 6. & $\begin{array}{l}\text { Peserta ekstrakurikuler } \\
\text { mempraktikkan teknik dasar } \\
\text { dollyo chagi sesuai dengan yang } \\
\text { ditayangkan dalam media }\end{array}$ & 11 & $\begin{array}{l}\text { Peserta ekstrakurikuler } \\
\text { mempraktikkan gerakan } \\
\text { teknik dasar dollyo chagi }\end{array}$ \\
\hline \multicolumn{4}{|c|}{ Aktivitas Emosional } \\
\hline 7. & $\begin{array}{l}\text { Peserta ekstrakurikuler senang } \\
\text { mengikuti arahan pelatih dan } \\
\text { video teknik dasar dollyo chagi } \\
\text { yang ada dalam media }\end{array}$ & 9 & $\begin{array}{l}\text { Terlihat peserta antusias dan } \\
\text { senang dengan adanya media } \\
\text { namun terdapat beberapa } \\
\text { peserta yang masih asyik } \\
\text { mengobrol sendiri dan } \\
\text { bersenda gurau. }\end{array}$ \\
\hline 8. & $\begin{array}{l}\text { Peserta ekstrakurikuler } \\
\text { bersemangat dalam mengikuti } \\
\text { kegiatan ekstarkurikuler } \\
\text { taekwondo }\end{array}$ & 10 & $\begin{array}{l}\text { Terdapat } 3 \text { peserta yang } \\
\text { terlihat lelah di akhir kegiatan } \\
\text { dan kehilangan semangat }\end{array}$ \\
\hline
\end{tabular}

Dari paparan hasil pengamatan aktivitas latihan teknik dasar dollyo chagi pada siklus II oleh peserta ekstrakurikuler taekwondo dapat diketahui terdapat 10 peserta memperhatikan video demonstrasi dan 11 peserta memperagakan teknik dasar sesuai dengan yang diperagakan dalam media, dari hasil tersebut dapat disimpulkan sebesar $96 \%$ dari jumlah keseluruhan peserta melakukan aktivitas visual. Peserta ekstrakurikuler mendengarkan suara sebanyak 9 orang dan 11 peserta menyimak instruksi yang disajikan pelatih, dapat dikatakan 90\% dari jumlah keseluruhan peserta melakukan aktivitas mendengarkan. Terdapat 10 
peserta fokus pada gerakan teknik dasar secara mandiri dan 11 peserta mempraktikkan gerakan mengikuti arahan pelatih dan media yang ditampilkan, dapat dikatakan terdapat $96 \%$ dari jumlah keseluruhan peserta melakukan aktivitas mental. Selain itu, 9 peserta juga senang mengikuti arahan pelatih dan 10 peserta bersemangat dalam mengikuti kegiatan menggunakan media, sehingga bisa dilihat $86 \%$ dari jumlah keseluruhan peserta melakukan aktivitas emosional.

Berdasarkan paparan data yang telah didapatkan pada siklus II maka persentase aktivitas latihan teknik dasar dollyo chagi secara keseluruhan adalah $92 \%$ yang dikategorikan masuk dalam kriteria "Sangat Baik". Hal ini mengalami kenaikan dari aktivitas latihan siklus I. Kemudian hasil pengamatan berupa data kuantitatif diperoleh dari pelaksanaan kegiatan evaluasi yang kemudian skor peserta dikonversikan menjadi persentase. Dari hasil yang dikonversikan kemudian diperlihatkan tingkat ketuntasan latihan teknik dasar dollyo chagi pada tabel 5.

Tabel 5. Tingkat Ketuntasan Latihan Teknik Dasar Dollyo Chagi Siklus II

\begin{tabular}{lccccc}
\hline Tingkat & \multicolumn{2}{l}{ Jumlah Peserta } & & Keseluruhan Peserta & Persentase \\
\cline { 2 - 4 } Keberhasilan & Pelatih I & Pelatih II & Peneliti & & \\
\hline Tercapai & 9 & 11 & 10 & 11 & $91 \%$ \\
Belum Tercapai & 2 & 0 & 1 & 11 & $9 \%$ \\
\hline
\end{tabular}

Berdasarkan data hasil belajar pada siklus II menunjukkan bahwa jumlah keseluruhan peserta ekstrakurikuler 11, terdapat 2 peserta ekstrakurikuler dari pelatih 1 dan 1 peserta ekstrakurikuler dari peneliti yang belum tercapai atau mendapatkan perolehan skor $\leq 70$. Kemudian untuk peserta ekstrakurikuler memperoleh skor $\geq 70$ terdapat 9 peserta dari pelatih 1, 11 peserta dari pelatih II dan 10 peserta dari peneliti. Persentase ketuntasan secara keseluruhan peserta ekstrakurikuler sebesar 91\% telah tercapai tingkat keberhasilan. Hal tersebut mengalami kenaikan hasil latihan teknik dasar dari siklus I. dapat disimpulkan bahwa siklus I mengalami peningkatan sebelum tindakan, dan siklus II mengalami peningkatan setelah siklus I.

Berdasarkan analisis data hasil belajar peserta ekstrakurikuler sebelum tindakan menunjukkan bahwa dari 11 peserta tingkat keberhasilan melakukan dollyo chagi sesuai dengan teknik yang benar mencapai 3\% dari jumlah total peserta keseluruhan. Pada siklus I setelah adanya penerapan media tingkat keberhasilan melakukan dollyo chagii dengan baik mencapai $82 \%$ dari jumlah total peserta keseluruhan. Hal tersebut mengalami kenaikan sebesar 79\% dari sebelum tindakan. Pada siklus II didapatkan hasil belajar mencapai tingkat keberhasilan sebesar 91\% dari jumlah total peserta keseluruhan. Kenaikan pada siklus I ke siklus II sebesar $9 \%$.

Penerapan media audio-visual yang menjadi faktor eksternal terhadap kegiatan ekstrakurikuler memberikan pengaruh pada hasil latihan, hal ini sesuai dengan pendapat (Rohani, 2019) bahwa memperhatikan kompleks dan uniknya proses belajar mengajar ketepatan memilih media dan metode dalam pembelajaran akan berpengaruh pada hasil belajar peserta didik. Hal ini menyebabkan terjadinya peningkatan dalam kualitas latihan di dalam kegiatan ekstrakurikuler taekwondo SMA pada materi dollyo chagi. Proses kegiatan ekstrakurikuler menjadi memiliki variasi dan membuat pelaksanaan semakin optimal serta 
peserta ekstrakurikuler lebih mudah memahami materi yang disajikan ketika berinteraksi langsung dengan media.

\section{Simpulan}

Dari hasil penelitian yang telah dipaparkan sebelumnya dapat dilihat bahwa penerapan media audio-visual Articulate Storyline dapat meningkatkan hasil belajar peserta dalam kegiatan ekstrakurikuler taekwondo di SMA. Hal ini sesuai dengan pendapat (Wulan, 2020) melalui implementasi media Articulate storyline dapat meningkatkan hasil belajar peserta didik. Berdasarkan hasil penelitian tindakan olahraga yang dilaksanakan pada kegiatan ekstrakurikuler taekwondo SMA bahwa penerapan media audio-visual pada materi teknik dasar dollyo chagi dapat meningkatkan hasil latihan peserta ekstrakurikuler taekwondo. Ketercapaian hasil ini sesuai dengan pengamatan pada peserta ekstrakurikuler dari sebelum tindakan, siklus I dan siklus II terjadi peningkatan pada setiap siklus yaitu persentase hasil belajar sebelum tindakan sebesar 3\%, setelah penerapan media interaktif meningkat pada siklus I sebesar $82 \%$ dan kembali meningkat pada siklus II sebesar 91\%. Hasil tersebut menunjukkan bahwa media audio-visual dapat meningkatkan hasil latihan peserta ekstrakurikuler taekwondo di SMA pada materi teknik dasar dollyo chagi.

\section{Daftar Rujukan}

Amiq, F. (2015). Sepak Bola (Sejarah, Teknik Dasar, Persiapan Fisik, Strategi, Peraturan Permainan). Malang: Univertas Negeri Malang.

Bremacker, M. d., \& Faige, R. (2010). The Essential Book of Martial Arts Kick. Singapore: Tuttle Publishing.

Kompri. (2015). Manajemen Pendidikan: Komponen-Komponen Elementer Kemajuan Sekolah. Yogyakarta: ArRuzz Media.

Louk, M. J., Neolaka, E. S., \& Runesi, S. (2020). The Effect of Audio Visual Media on Cognitive Affective Development and Student Psychomotors in Futsal Game Learning. Journal of Physical Education Health and Sport Sciences, 1(1), 1-8.

Muhson, A. (2010). Pengembangan Media Pembelajaran Berbasis Teknologi Informasi. Jurnal Pendidikan Akuntansi Indonesia, 8(2), 1-10.

Rachmahani, W. (2017). Efektivitas Tendangan Checking Yeop Chagi, Dollyo Chagi, dalam Membuka Serangan pada Pertandingan Taekwondo Kyorugi Kelas Senior di UPI Challenge National Taekwondo Championship Tahun 2016. Jurnal Pendidikan Jasmani, Kesehatan dan Rekreasi, 4(4), 68.

Rohani, R. (2019). Media Pembelajaran. Sumatera Utara: UIN.

Setianto, W. R., Widijoto, H., \& Sulistyorini, S. (2017). Pengembangan Latihan Taekwondo dengan Media AudioVisual untuk Ekstrakurikuler Taekwondo di SMA Kabupaten Tulungagung. Gelanggan Pendidikan Jasmani Indonesia, 1(1), 30-39.

Surjono, H. K. (2017). Multimedia Pembelajaran Interaktif Konsep dan Pengembangan. Yogyakarta: UNY Press.

Suryadi, V. Y. (2003). Taekwondo Poomse Tae Geuk. Jakarta: PT Gramedia Pustaka Utama.

Wiyani, N. A. (2013). Menumbuhkan Pendidikan Karakter di SD (Konsep. Praktek, dan Strategi). Yogyakarta: Ar-Ruzz Media.

Wulan, C. A. (2020). Implementasi Media Interaktif Articulate Storyline dalam Meningkatkan Aktivitas dan Hasil Belajar Subtema Indahnya Persatuan dan Kesatuan Negeriku di Kelas IV SDN Cemorokandang 2 Kota Malang. Malang: FIP UM. 